\title{
DOES WIDOWHOOD EXPLAIN GENDER DIFFERENCES IN OUT-OF-POCKET MEDICAL SPENDING AMONG THE ELDERLY?
}

\author{
Gopi Shah Goda \\ John B. Shoven \\ Sita Nataraj Slavov \\ Working Paper 17440 \\ http://www.nber.org/papers/w17440 \\ NATIONAL BUREAU OF ECONOMIC RESEARCH \\ 1050 Massachusetts Avenue \\ Cambridge, MA 02138 \\ September 2011
}

This research was supported by the U.S. Social Security Administration through grant \#5 RRC08098400-03-00 to the National Bureau of Economic Research as part of the SSA Retirement Research Consortium. The findings and conclusions expressed are solely those of the author(s) and do not represent the views of SSA, any agency of the Federal Government, or the NBER. We would like to thank participants at the NBER Summer Institute for helpful comments.

NBER working papers are circulated for discussion and comment purposes. They have not been peerreviewed or been subject to the review by the NBER Board of Directors that accompanies official NBER publications.

(C) 2011 by Gopi Shah Goda, John B. Shoven, and Sita Nataraj Slavov. All rights reserved. Short sections of text, not to exceed two paragraphs, may be quoted without explicit permission provided that full credit, including $\odot$ notice, is given to the source. 
Does Widowhood Explain Gender Differences in Out-of-Pocket Medical Spending Among the Elderly?

Gopi Shah Goda, John B. Shoven, and Sita Nataraj Slavov

NBER Working Paper No. 17440

September 2011

JEL No. I11,J12,J14,J16

\begin{abstract}
Despite the presence of Medicare, out-of-pocket medical spending is a large expenditure risk facing the elderly. While women live longer than men, elderly women incur higher out-of-pocket medical spending than men at each age. In this paper, we examine whether differences in marital status and living arrangements can explain this difference. We find that out-of-pocket medical spending is approximately 29 percent higher when an individual becomes widowed, a large portion of which is spending on nursing homes. Our results suggest a substantial role of living arrangements in out-of-pocket medical spending; however, our estimates combined with differences in rates of widowhood across gender suggest that marital status can explain only one third of the gender difference in total out-of-pocket medical spending, leaving a large portion unexplained. On the other hand, gender differences in widowhood more than explain the observed gender difference in out-of-pocket spending on nursing homes.
\end{abstract}

Gopi Shah Goda

Stanford University

SIEPR

366 Galvez St.

Stanford, CA 94305

and NBER

gopi@ stanford.edu

John B. Shoven

Department of Economics

579 Serra Mall at Galvez Street

Stanford, CA 94305-6015

and NBER

shoven@1eland.stanford.edu
Sita Nataraj Slavov

Department of Economics

Occidental College

1600 Campus Road

Los Angeles, CA 90042

sslavov@oxy.edu 


\section{Introduction}

It is well known that women tend to outlive men. The average 65-year-old woman has a remaining life expectancy of 20.0 years, compared to 17.3 years for the average 65 -year-old man (Kochanek et al. 2011). However, despite longer remaining life expectancies, out-of-pocket medical spending is higher for women than for men. Figure 1 depicts total out-of-pocket medical spending averaged over five-year age groups for males and females. The figure shows both that average spending is higher for women in each age group and that the difference appears to increase at higher ages.

There are a number of possible explanations for this empirical finding. For example, differences in preferences or insurance coverage can cause out-of-pocket medical spending to vary across individuals. An alternative explanation - which we investigate in this paper - comes from the fact that women tend to live longer and marry older men. Therefore, older women are more likely to be widowed. Widowhood may result in higher out-of-pocket expenses for a couple of reasons. First, widowhood may be accompanied by changes in insurance coverage or health status. A widow's own health may decline - or she may lose private insurance coverage upon the death of her spouse. Second, widows are more likely to live alone, and living alone can result in higher out-of-pocket medical expenses because a spouse or partner may substitute for paid caregivers. Because rates of private long-term care insurance are low and Medicaid longterm care eligibility requires one to spend down their resources to qualify, out-of-pocket medical spending is particularly vulnerable to the risk of nursing home or home care expenses. Indeed, as shown in Figure 2, there is a large gender difference in spending on nursing homes, particularly at higher ages. 
In this paper, we examine the impact of marital status, and in particular, widowhood, on different components of out-of-pocket medical spending and health care utilization. As there may be selection into marriage, we use within-person changes in marital status to identify its causal effects. Because our analysis covers a relatively short time period of 6 years, this method allows us to measure the near-term effects of widowhood rather than the long-term effects of widowhood. We find that monthly out-of-pocket medical spending is $\$ 43.06$, or about 29 percent, higher for widows relative to those who are married. This increase is primarily driven by nursing home utilization. Out-of-pocket nursing home expenditures increase by $\$ 24.82$ per month, accounting for 58 percent of the increase, and the average number of nursing home nights over a 2-year period increases by 6.3. We find that these results are not driven by observable changes in health (as measured by self-reported health status, the number of health conditions, and limitations in activities of daily living) or sources of insurance, which suggests that living arrangements may be the underlying cause of the increase in out-of-pocket expenses. We also find that the effect of marital status on out-of-pocket medical spending does not differ by gender.

While the effect of widowhood on monthly out-of-pocket medical spending is nontrivial and statistically significant, it does not explain a substantial portion of the gender differences in overall out-of-pocket medical spending. Our simulations suggest that differences in marital status and living arrangements by gender explain approximately one third of the difference in male and female medical spending for individuals age 55 and older, leaving a considerable amount due to other factors. However, accounting for differences in marital status reverses the gender differences in out-of-pocket spending on nursing homes, implying that widowhood is an important factor in nursing home demand. 
This paper is organized as follows. Section 2 reviews the relevant literature and describes the contribution of this research. Section 3 describes our data, Section 4 presents our methodology, and Section 5 summarizes our results. Section 6 details our simulations to determine the amount of out-of-pocket medical spending explained by marital status, and Section 7 offers conclusions.

\section{Literature Review}

There is a large literature on risk factors for nursing home entry. Recent systematic reviews (Luppa et al. 2010; Gaugler et al. 2007; Miller and Weissert 2000) suggest that being single is consistently associated with greater probability of nursing home entry. Other predictors that emerge across a number of studies include female gender and living alone, although the studies reviewed by Luppa et al. (2010) find inconsistent results for these factors. These studies generally exploit cross-section variation in risk factors to study their effects. Consistent with these findings, Lakdawalla and Philipson (2002) argue that an increase in the elderly population can reduce long-term care use because healthy elderly people serve as caregivers to those in poor health. In particular, if growth in the elderly population is accompanied by an increase in the ratio of males to females, the number of elderly widows - and thus use of long-term care - falls. Their empirical analysis, based on aggregate county-level data, suggests that a decrease in the share of elderly men contributed substantially to the observed increase in nursing home care during the 1970s.

A related strand of research concerns the impact of care by family members (informal care) on the use of care by professionals (formal care). In studying this impact, it is important to account for the fact that the level of formal and informal care are jointly determined, and that unobservable aspects of health status could be correlated with the receipt of both formal and 
informal care. Bonsang (2009), Van Houtven and Norton (2004, 2008), Bolin et al. (2007), Lo Sasso and Johnson (2002), Charles and Sevak (2005), and Greene (1983) use an instrumental variables approach to examine the impact of informal care on the utilization of formal care. In general, these studies find that informal care by children reduces use of formal care, especially home care and nursing home stays. Instruments for informal care in these studies include children's characteristics (e.g., the genders of the children, as daughters are more likely to provide care), ethnicity, and proximity of family. Pezzin et al. (1996) find that public expenditures on home care reduce informal care provided by family, and Pezzin and Shone (1999) find that paid home health care is a substitute for care by children. In an extension of their earlier work, Van Houtven and Norton (2008) further show that care by children significantly reduces Medicare long-term care expenses for single parents; however, this effect is reduced for married parents.

Some earlier studies have examined the relationship between out-of-pocket medical spending and the saving behavior among elderly (e.g., DiNardi, French, and Jones 2010; French and Jones 2004; Palumbo 1999; Hubbard, Skinner, and Zeldes 1994; Kotlikoff 1988). While marital status is not the main focus of these studies, French and Jones (2004) do find that, after controlling for insurance coverage, males have lower costs, while married individuals have higher costs.

Our work extends this literature in several ways. First, there is a large literature on the impact of widowhood on income and wealth, and some of this literature focuses on the role of the out-of-pocket spending of the deceased spouse (see, e.g., McGarry and Schoeni 2005). However, we are not aware of other work examining the impact of widowhood on the widow's 
own out-of-pocket medical expenses. ${ }^{1}$ Second, our work complements the literature on nursing home utilization by showing the extent to which increased nursing home utilization among single individuals translates into higher monetary costs. Moreover, to identify the causal effects of marital status, we focus on the impact of marital status transitions on out-of-pocket spending. Thus, we use within-person, rather than cross-sectional, variation in marital status to identify the impact of widowhood on out-of-pocket spending. It is important to note, however, that an analysis based on marital status transitions over a relatively short time period can only measure the near-term impact of shocks to marital status. One might expect the impact of widowhood to be different for long-term widows compared to the recently widowed.

\section{Data}

Our data come from the Health and Retirement Study (HRS), a biennial panel survey that is designed to be representative of the population aged 50 and older. The HRS began with a group of non-institutionalized respondents in 1992, but continued to follow them even if they subsequently became institutionalized. Additional respondents were added in later waves to keep the sample representative of the target population. The HRS includes demographic information, as well as detailed data on health status, insurance coverage, and health care spending and utilization. We restrict attention to the four waves from 2002-2008, as the components of medical spending are reported in a consistent way across these waves. We also restrict attention to individuals aged 55 and older.

The HRS includes person-level weights, which can be used to make the survey data match the characteristics of the non-institutionalized elderly population. Thus, anyone who is in a

\footnotetext{
${ }^{1}$ McGarry and Schoeni (2005) do report the expenditures of the surviving spouse just before and after widowhood, but focus mostly on the expenses of the spouse who died.
} 
nursing home at the time of interview receives a weight of zero. Excluding individuals who are in a nursing home at the time of interview effectively excludes long-term nursing home residents, who are likely to represent a large share of out-of-pocket medical expenses. Because nursing home expenditures are central to our analysis, we report our results without using the HRS weights. However, we also examine the sensitivity of our analysis to excluding nursing home residents.

Most of the variables used in our analysis - including medical care utilization, insurance coverage, health status, and demographics - come from the RAND version of the HRS data. However, because the RAND dataset includes only total out-of-pocket spending, we must merge in data on the components of medical spending from the raw HRS data. Because of imputations and other adjustments that were made by RAND researchers, the components of medical spending from the raw data do not necessarily sum to the total from the RAND data. Thus, we create our own measure of total out-of-pocket spending by summing the individual components from the raw data. The components of medical spending include spending on hospitals, nursing homes, outpatient surgery, doctors, dental, prescription drugs, home health care, and other services. The medical utilization measures include the number of doctor visits, hospital stays, hospital nights, and nursing home nights, as well as indictors for whether the respondent had doctor visit, hospital stay, home care, prescription drugs, outpatient surgery, dental visit, or other medical care use. ${ }^{2}$

In each wave, individuals are asked to report their out-of-pocket medical spending and utilization since the last interview. New respondents are asked about their spending and

\footnotetext{
${ }^{2}$ The "other" category for both spending and utilization generally includes special facilities, such as an adult care center, outpatient rehabilitation, transportation or meal services, or a social worker.
} 
utilization over the previous two years. For all components of medical spending except prescription drugs, respondents are asked about their total spending during the reference period; for prescription drugs, respondents are asked to provide the average monthly amount during the period. All of the utilization questions refer to total utilization during the reference period. If an individual was in the previous wave, the average reference period is 24 months, although it varies from 13 to 36 months. We exclude individuals who were not interviewed in the previous wave, and are not new interviewees, as the reference period for these individuals could be much longer than two years, and some utilization measures cannot easily be adjusted for different lengths. We convert all out-of-pocket spending amounts (except for prescription drugs) to average monthly values by dividing by the appropriate reference period. We also use the Consumer Price Index (CPI-U) for medical care to convert all out-of-pocket spending variables to 2010 dollars, where the base year for the conversion is the year in which the interview took place.

One shortcoming of our out-of-pocket spending measures is that they do not include insurance premiums. The raw HRS data do contain information about premiums for private health insurance, Medicare Advantage, Medicare Part D, and long-term care insurance; however, the insurance may cover individuals other than the respondent. Though the HRS reports if other family members are covered, we do not know what fraction of the premium paid is for the other family member. Thus, we cannot compute an individual-level amount for insurance premiums. Therefore, our analysis focuses on non-insurance out-of-pocket medical spending.

Our key independent variable is marital status. The HRS marital status variable has seven categories: (1) married, (2) married - spouse absent, (3) partnered, (4) separated, (5) divorced, (6) widowed, and (7) never married. We define an individual as married if he or she falls into 
categories (1)-(3). In certain specifications, we include dummy variables indicating whether an individual is covered by Medicare, Medicaid, VA/CHAMPUS, a private insurance plan (which includes a plan offered by the respondent's employer, the spouse's employer, and any other plan besides government or employer-provided), or a long-term care insurance plan.

We also examine the role of own-health changes, by including measures of the respondent's self-reported health status, health conditions, and difficulties with activities of daily living. In each wave, respondents are asked to report a self-assessment of their health on a scale of 1-5, with 1 being excellent and 5 being poor. The RAND HRS includes an index indicating the number of health conditions with which the individual has ever been diagnosed, including high blood pressure, diabetes, cancer, lung disease, heart disease, stroke, psychiatric problems, and arthritis. The RAND HRS also includes indices of the number of activities of daily living (ADLs) and instrumental activities of daily living (IADLs) with which the respondent reports "some difficulty." The activities included in the ADL index are bathing, dressing, walking across a room, getting in or out of bed, and eating. The activities included in the IADL index are using a telephone, taking medication, shopping, preparing meals, and handling money.

Table 1 provides summary statistics for all variables used in our analysis, measured at the person-year level and reported separately by marital status. Women are more likely to be single than men, and the vast majority of single respondents are widowed. Single respondents also report higher out-of-pocket medical spending, particularly for nursing homes. Figure 3 summarizes total out-of-pocket spending by marital status, gender and age, and Figure 4 does the same for spending on nursing homes. Figures 3 and 4 suggest that marital status may be able to explain some, but not all, of the gender difference in out-of-pocket spending. Within both 
genders, single people have higher out-of-pocket spending than married people. However, within the same marital status, women still tend to have higher out-of-pocket expenses than men.

\section{Methods}

Figures 3 and 4 suggest that marital status may play a part in explaining gender differences in out-of-pocket spending. However, these figures are based on cross-sectional variation in marital status. The single group includes those who are recently widowed as well as those who have been widowed for many years, and therefore the figures include both the near-term and long-term effects of marital status. Moreover, the single category includes never married and divorced individuals, a group that is potentially selected based on unobservable characteristics. We conduct our empirical analysis by examining within-person changes in marital status using individual fixed effects. This approach isolates the near-term, causal effects of marital status.

We begin by estimating regressions of the following form:

$$
y_{i t}=\alpha_{1} w_{i t}+\alpha_{2} d_{i t}+\alpha_{3} s_{i t}+\mu a_{i t}+\gamma_{i}+\delta_{t}+\varepsilon_{i t} \text {, }
$$

where $y_{i t}$ is any of our measures of out-of-pocket spending or utilization, $w_{i t}$ is a dummy indicating whether individual $i$ is widowed in year $t, d_{i t}$ is a dummy indicating whether individual $i$ is divorced in year $t, s_{i t}$ is a dummy indicating whether individual $i$ is single (never married) in year $t, a_{i t}$ is a vector of age dummies for individual $i$ in year $t, \gamma_{i}$ is an individual fixed effect, $\delta_{t}$ is a year (wave) effect, and $\varepsilon_{i t}$ is a stochastic error term. The $\alpha$ 's measure the impact of being widowed, divorced, or single relative to the reference category of married. We estimate (1) for each of our spending and utilization measures.

When an individual transitions from being married to single or vice versa, his or her health insurance coverage may change. While insurance directly lowers out-of-pocket spending, the 
overall impact on out-of-pocket medical spending could be positive or negative because of increased utilization due to moral hazard. In addition, an individual's own health condition may also change upon becoming widowed, divorced, or married. Therefore, we add to (1) controls describing each individual's health and insurance status as described in the previous section. We allow for full nonlinearity by including each set of variables as indicator variables. If controlling for health and insurance status substantially reduces the magnitude of the estimated $\alpha$ 's, it would suggest that changes in out-of-pocket medical spending that occur with changes in marital status are driven by changes in insurance or health status. Finally, we test whether women are more vulnerable than men to the effect of marital status by estimating (1) with the marital status dummies interacted with gender.

We also conduct a series of sensitivity analyses and robustness checks. Because our definition of married includes a small number of respondents who report their spouses being absent (largely because either they or their spouses are in nursing homes), we include a separate dummy for whether the individual's spouse is in a nursing home. We also estimate (1) only for individuals with no children in order to determine whether having no children makes individuals more vulnerable to the effects of widowhood. In addition, we estimate (1) for individuals who fall within the $5^{\text {th }}-95^{\text {th }}$ percentile of out-of-pocket spending for their 5 -year age group. This illustrates the extent to which our findings are driven by outliers. Finally, we estimate (1) only for households where neither spouse is in a nursing home at the time of interview. As discussed earlier, this restriction effectively excludes long-term nursing home residents and illustrates the extent to which spending by this group drives our results. In all of our regressions, standard errors are clustered by household in order to account for the fact that individuals from the same household may have correlated shocks to out-of-pocket spending or utilization. 


\section{Results}

Table 2 summarizes the results from estimating (1) on total out-of-pocket medical spending and its components. The results indicate that being widowed is associated with $\$ 43.06$ in additional monthly out-of-pocket medical spending relative to being married. This amount represents a 29 percent increase in the average monthly out-of-pocket medical spending for married respondents and is statistically significant at conventional levels, though the coefficient has a large standard error. The main driver of this increased spending is spending on nursing home care: individuals spend on average \$24.82 monthly in additional out-of-pocket nursing home care when widowed relative to $\$ 2.98$ spent on average while married. Because the regressions include individual fixed effects, these estimates are identified off of changes in marital status within individuals over time. Age and year fixed effects capture differences in outof-pocket spending common to all individuals of a particular age and time trends common to all respondents.

With the exception of out-of-pocket dental spending, the remaining categories of out-ofpocket spending show no statistically significant relationship of widowhood. In addition, we find no evidence that being separated/divorced or never married is associated with higher out-of-

pocket medical spending overall, though both of these groups experience higher levels of nursing home spending relative to married individuals.

Given that our analysis focuses on out-of-pocket medical spending and not overall health spending, if individuals have generous insurance coverage, health care utilization may change with marital status without changing out-of-pocket medical spending. Table 3 summarizes the results of estimating (1) using various measures of health care utilization as the dependent 
variable. Columns (1) through (8) show the effect of marital status on extensive measures of health care utilization which measure whether the respondent utilized different types of care over the appropriate reference period. Widowhood is associated with higher rates of outpatient surgery, nursing home stays, home health care, and use of special health facilities. The coefficients are large in magnitude: the probability of reporting a nursing home stay increases by over 70 percent. Separation or divorce is associated with higher rates of outpatient surgery and nursing home stays, while never married respondents do not exhibit health care utilization different from those who are married. Table 3 also shows the results of estimating (1) using intensive measures of health care utilization in columns (9) through (12). Perhaps unsurprisingly, all respondents spend significantly more nights in nursing homes when unmarried relative to when they are married. However, the results show no evidence that the number of hospital stays, doctor visits and hospital nights change with changes in marital status.

We next examine whether the effects of marital status on out-of-pocket medical spending alter when we control for health status and health insurance, which may also change when marital status changes. These results are reported in Table 4. The estimated coefficients on widowhood are smaller in magnitude but change only slightly after the additional controls are incorporated, suggesting that very little of the effects of widowhood on out-of-pocket medical spending are due to worsened health status or poorer insurance. A spouse often substitutes for paid caregivers; in the absence of this form of insurance, individuals often find themselves needing nursing home care. This effect is likely due to the fact that insurance against long-term care risk is often inadequate: only 12 percent of our sample owns private long-term care insurance and Medicare does not cover extended use of long-term care, leaving many to spend down their resources until eligible for long-term care services through Medicaid. 
Finally, we analyze whether females are more vulnerable to widowhood than their male counterparts by estimating interacted versions of (1) which allow us to determine whether the effects we estimate differ across gender. Table 5 reports our findings. For all components of out-of-pocket medical spending, the coefficient on the marital status $\mathrm{X}$ gender interaction terms are statistically insignificant, suggesting there is no evidence of a gender difference in the effect of marital status on out-of-pocket medical spending. The main effects of marital status are less precisely estimated, though the magnitudes are very similar to those we report in Table 2 .

Table 6 reports the results of four different sensitivity and robustness checks. We report the results for total out-of-pocket medical spending and that spent on nursing homes, but omit the other components of out-of-pocket spending for simplicity. Columns (1) and (2) report the results of including an additional control variable indicating whether one's spouse is in a nursing home. Having a spouse in a nursing home is highly correlated with being in a nursing home oneself; thus, it is not surprising to find a large, positive coefficient on this variable in the nursing home expenditures regression. Columns (3) and (4) report the results of estimating equation (1) for individuals with no children. None of the marital status coefficients are statistically significant, providing no evidence that individuals without children are more vulnerable to the effects of widowhood. We note, however, that the number of individuals with no children is small. Columns (5) and (6) report the results of estimating equation (1) for individuals who fall into the $5^{\text {th }}$ through $95^{\text {th }}$ percentile of out-of-pocket spending for their age group. Now widowhood no longer has a statistically significant impact on total out-of-pocket spending, and it has a much smaller (statistically significant) impact on nursing home spending. These results suggest that most of the effects of widowhood are concentrated among a small group in the form of catastrophic medical spending. Finally, columns (7) and (8) report the 
results from estimating equation (1) on individuals who are not in a nursing home at the time of interview. Now widowhood no longer has a statistically significant impact on out-of-pocket spending, suggesting that long-term nursing home stays play a large role in our results.

\section{Simulation Exercise}

While our results suggest that marital status has a nontrivial effect on out-of-pocket medical spending, our analysis thus far does not indicate whether the effect we estimate can explain the gender differences in out-of-pocket medical spending depicted in Figure 1.

Therefore, we use our results to conduct a simulation to determine what portion of the gender difference in out-of-pocket medical spending is accounted for by differences in marital status across gender.

We define:

$$
\bar{z}_{a, g}=\frac{\sum_{i=1}^{N_{a, g}} \hat{\gamma}_{i}}{N_{a, g}}
$$

where $N_{a, g}$ is the number of person-year observations of gender $g$ and age group $a$, and $\hat{\gamma}_{i}$ is the estimated individual fixed effect from (1). In other words, $\bar{z}_{a, g}$ is the mean of the estimated individual fixed effects from specification (1) for age group $a$ and gender $g$, calculated across all person-year observations in age group $a$ and gender $g$. The difference $\bar{z}_{a, \text { women }}-\bar{z}_{a, \text { men }}$ is the gender difference in unexplained out-of-pocket spending after accounting for marital status differences in out-of-pocket spending and differences in marital status across gender.

We then estimate an alternative specification

$$
y_{i t}=\gamma_{i}^{\prime}+\mu^{\prime} a_{i t}+\delta_{t}^{\prime}+\varepsilon^{\prime}{ }_{i t}
$$


which is the same as (1) but does not include the marital status dummies. We define $\bar{Z}_{a, g}^{\prime}$ analogously for specification (2) for each age group $a$ and gender $g$. The difference $\bar{Z}_{a, \text { women }}^{\prime}-\bar{Z}_{a, m e n}^{\prime}$ is the gender difference in unexplained out-of-pocket spending without controlling for marital status. Finally, we compute the following measure for each age group $a$ :

$$
\theta_{a}=1-\frac{\bar{Z}_{a, \text { women }}-\bar{Z}_{a, \text { men }}}{\bar{Z}_{a, \text { women }}^{\prime}-\bar{Z}_{a, \text { men }}^{\prime}}
$$

The value $\theta_{a}$ represents the share of the gender difference in out-of-pocket spending of age group $a$ that is explained by marital status.

Table 7 reports $\bar{z}_{a, \text { women }}-\bar{z}_{a, \text { men }}$ for both specifications (1) and (2), as well as $\theta_{a}$ for each of the 5-year age groups included in Figure 1 and for the sample overall. Panel (a) reports the results for total out-of-pocket medical spending, and (b) restricts to out-of-pocket spending on nursing homes. These results suggest that across age groups, marital status can explain about 35 percent of the raw gender difference in total out-of-pocket spending. Marital status tends to explain a larger percentage of the gender difference for older age groups. While the effect of marital status is nontrivial, it still leaves a large fraction of the gender difference in out-of-pocket spending unexplained.

Panel (b) suggests that accounting for differences in marital status across gender reverses the relationship of out-of-pocket spending on nursing homes between men and women. When controls for marital status are not included, average out-of-pocket nursing home spending is higher for women. However, with the addition of marital status controls, men have higher levels of unexplained out-of-pocket spending on nursing homes. Therefore, accounting for marital status differences explains more than the entire gender difference in out-of-pocket spending on nursing homes. 


\section{Conclusions}

Despite the presence of near-universal insurance by Medicare, out-of-pocket medical spending constitutes a large expenditure risk facing the elderly. One of the largest components of this risk is spending on nursing home care because private insurance coverage for long-term care expenses is low and eligibility for Medicaid coverage of long-term care requires an almost complete spend-down of financial resources.

In this paper, we show that living with one's spouse appears to at least partially proxy for paid caregivers, as nursing home costs increase substantially with widowhood, even after controlling for changes in health and insurance status. The increased nursing home costs generate an increase in total out-of-pocket medical spending of approximately 29 percent for widowed elderly relative to married elderly. By including individual fixed effects, our analysis uses marital status changes, rather than long-standing differences in marital status, to identify the near-term, causal effects of marital status.

While the effect we find is fairly substantial, increase out-of-pocket spending by widows and the higher number of widows who are women cannot account for the majority of the gender difference in total out-of-pocket medical spending by the elderly. Though we find that living arrangements can explain more than the raw gender difference in nursing home spending, our simulations suggest that living arrangements account for approximately 35 percent of the difference in total out-of-pocket medical spending. The remainder could be due to a variety of additional factors, such as gender differences in health status, health care utilization conditional on health status, or insurance generosity. Examining the drivers of the gender differences remains an important area for future research. 


\section{References}

Bolin, K, B. Lindgren and P. Lundborg (2007). "Informal and Formal Care Among SingleLiving Elderly in Europe." Health Economics, 10(1002).

Bonsang, E. (2009). "Does Informal Care From Children to Their Elderly Parents Substitute for Formal Care in Europe?” Journal of Health Economics, 143(154), p144-154.

Charles, Kerwin and Purvi Sevak (2005). "Can Family Caregiving Substitute for Nursing Home Care?” Journal of Health Economics, 24, p1174-1190.

De Nardi, Mariacristina, Eric French and John Bailey Jones (2010). "Why Do the Elderly Save? The Role of Medical Expenses.” Journal of Political Economy, 119(1), p39-75.

French, Eric and John Jones (2004). "On the Distribution and Dynamics of Health Care Costs." Journal of Applied Econometrics, 19(6), p705-721.

Gaugler, Joseph, Sue Duval, Keith Anderson, and Robert Kane (2007). "Predicting Nursing Home Admission in the U.S: a Meta-Analysis." BioMed Central Geriatrics Journal, 7(13), p1-14.

Greene, Vernon (1983). "Substitution Between Formally and Informally Provided Care for the Impaired Elderly in the Community." Medical Care, 21(6), p609-619.

Hubbard, R. Glenn, Jonathan Skinner and Stephen Zeldes (1994). "The Importance of Precautionary Motives in Explaining Individual and Aggregate Saving." CarnegieRochester Conference Series on Public Policy, Elsevier, 40(1), p59-125.

Kochanek, Kenneth D., Jiaquan Xu, Sherry L. Murphy, Arialdi M. Minino and Hsiang-Ching Kung (2011). "Deaths: Preliminary Data for 2009," National Vital Statistics Report, 59 (4), p1-68.

Kotlikoff, Laurence (1998). "Intergenerational Transfers and Savings." Journal of Economic Perspectives, 2(2), p41.

Lakdawalla, Darius and Tomas Philipson (2002). "The Rise in Old-Age Longevity and the Market for Long-Term Care.” American Economic Review, 92(1), p295-306.

Lo Sasso, Anthony and Richard Johnson (2002). "Does Informal Care from Adult Children Reduce Nursing Home Admissions for the Elderly?" Inquiry, 39(3), p279-297.

Luppa, Melanie, Tobias Luck, Siegfried Weyerer, Hans-Helmut Konig, Elmar Brahler and Steffi Riedel-Heller (2010). "Prediction of Institutionalization in the Elderly. A Systemic Review." Age and Ageing 39, p31-38.

McGarry, Kathleen and Robert Schoeni (2005). "Medicare Gaps and Widow Poverty.” Social 
Security Bulletin, 66(1), p58-78.

Miller, Edward and William Weissert (2000). "Predicting Elderly People's Risk for Nursing Home Placement, Hospitalization, Functional Impairment, and Mortality: A Synthesis." Medical Care Research and Review, 57(3), p259-297.

Palumbo, Michael (1999). "Uncertain Medical Expenses and Precautionary Saving Near the End of the Life Cycle." Review of Economic Studies, 66, p395-421.

Pezzin, Liliana, Peter Kemper and James Reschovsky (1996). "Does Publicly Provided Home Care Substitute for Family Care? Experimental Evidence with Endogenous Living Arrangements." Journal of Human Resources, 31(3), p650-676.

Pezzin, Liliana and Barbara Steinberg Schone (1999). "Intergenerational Household Formation, Female Labor Supply and Informal Caregiving: A Bargaining Approach.” Journal of Human Resources, 34(3), p475-503.

Van Houtven, Courtney and Edward Norton (2004). "Informal Care and Health Care Use of Older Adults." Journal of Health Economics, 23, p1159-1180.

Van Houtven, Courtney and Edward Norton (2008). "Informal Care and Medicare Expenditures: Testing for Heterogeneous Treatment Effects." Journal of Health Economics, 27, p134156. 
Figure 1: Monthly Out-of-Pocket Medical Spending by Age and Gender (Total)

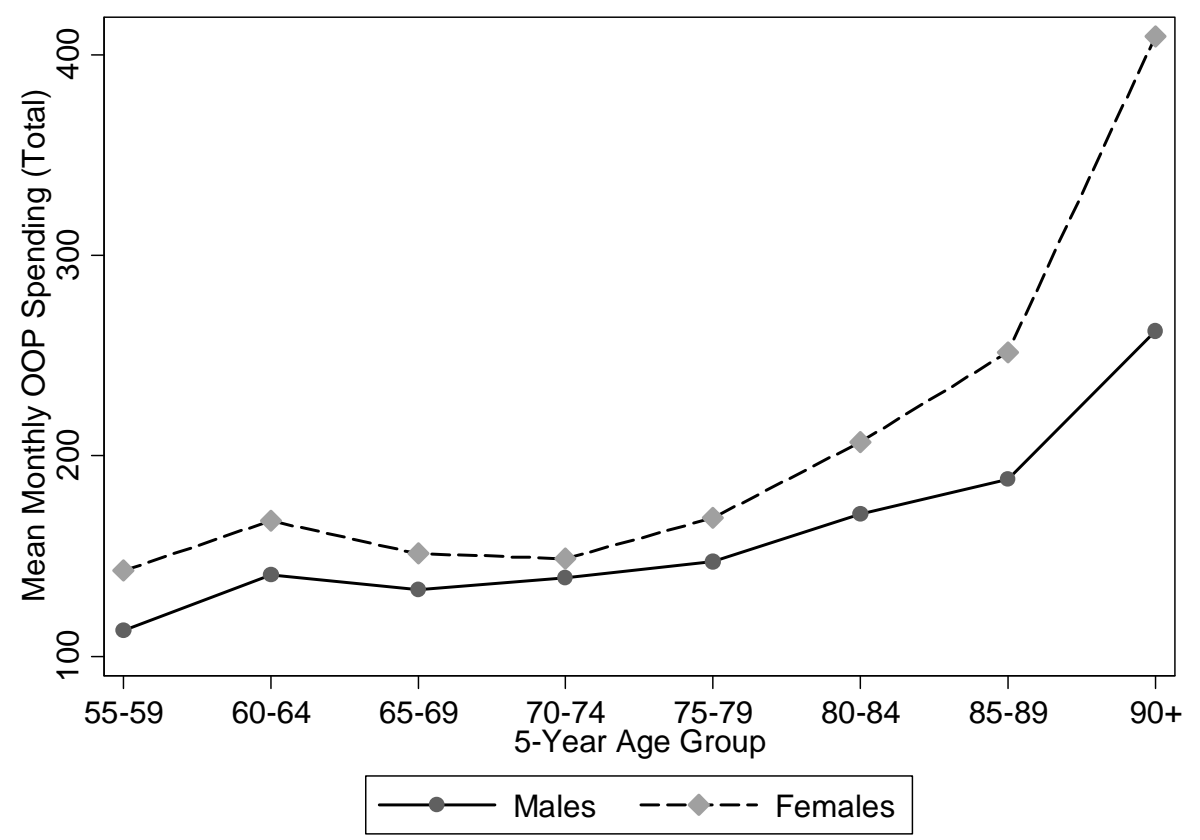

Source: Health and Retirement Study (HRS), Waves 5-9, 2002-2008.

Note: All figures in 2010 dollars.

Figure 2: Monthly Out-of-Pocket Medical Spending by Age and Gender (Nursing Home)

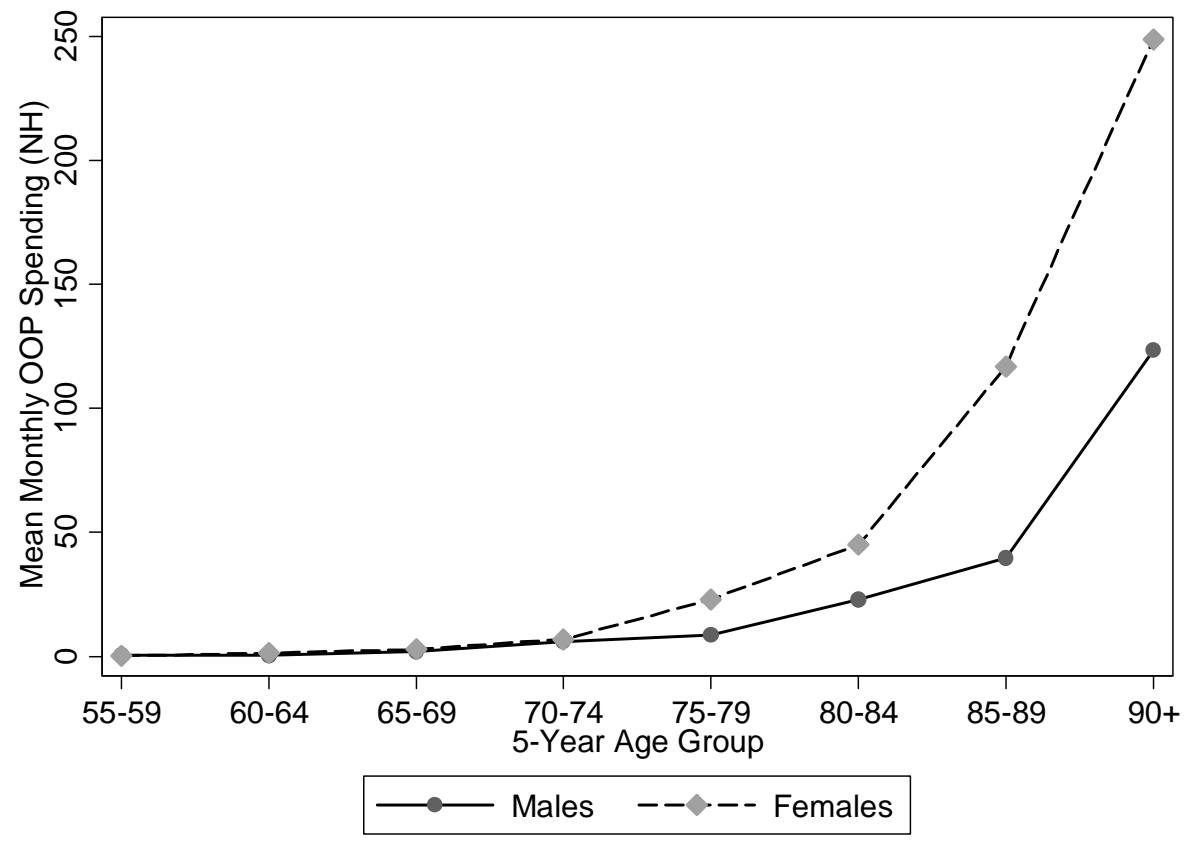

Source: Health and Retirement Study (HRS), Waves 5-9, 2002-2008.

Note: All figures in 2010 dollars. 
Figure 3: Monthly Out-of-Pocket Medical Spending by Age, Gender and Marital Status (Total)

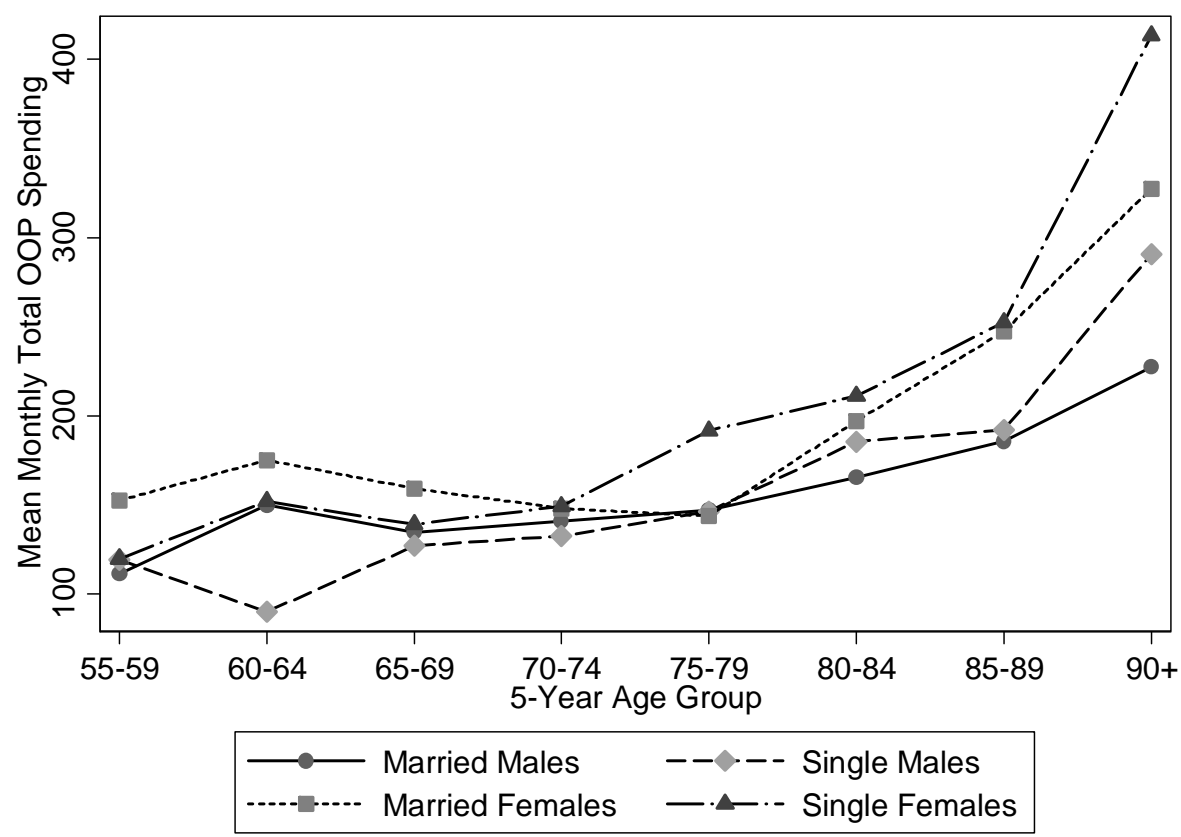

Source: Health and Retirement Study (HRS), Waves 5-9, 2002-2008.

Note: All figures in 2010 dollars.

Figure 4: Monthly Out-of-Pocket Medical Spending by Age, Gender and Marital Status (Nursing Home)

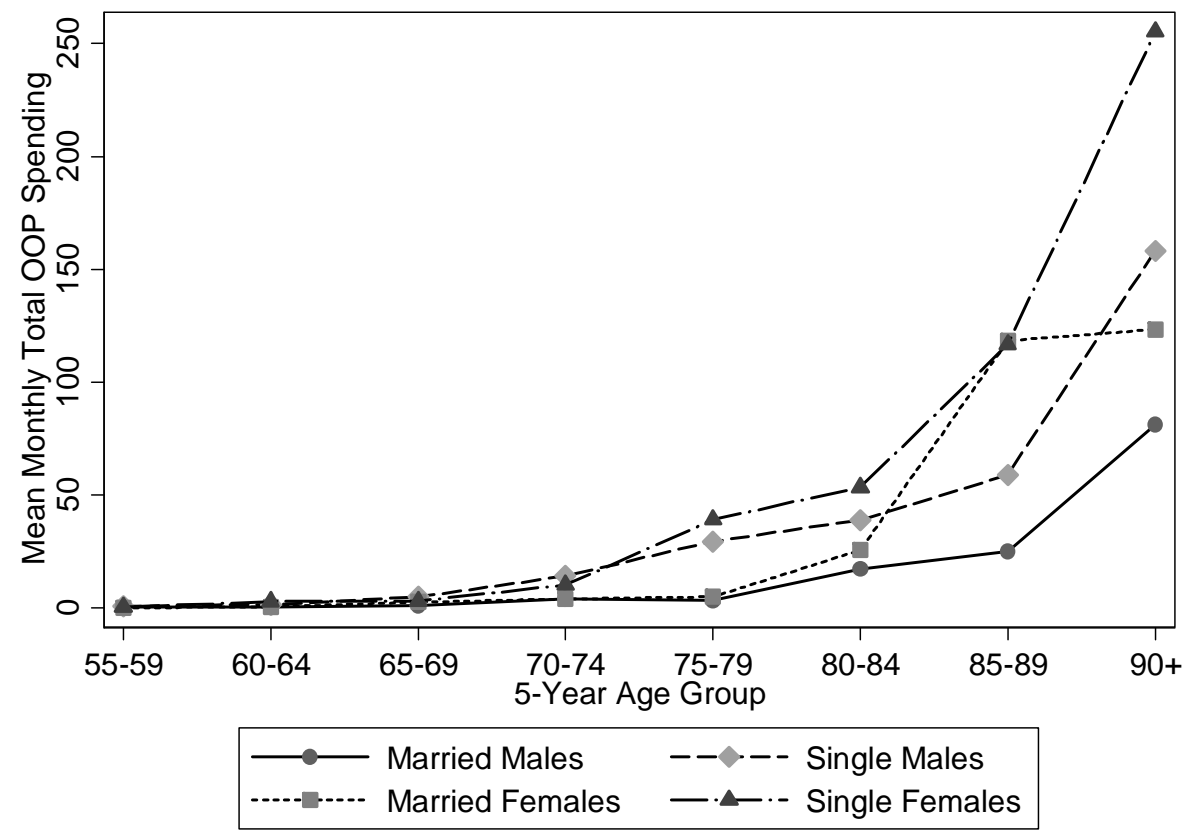

Source: Health and Retirement Study (HRS), Waves 5-9, 2002-2008.

Note: All figures in 2010 dollars. 
Table 1: Summary Statistics

\begin{tabular}{|c|c|c|c|c|c|c|c|c|}
\hline & \multicolumn{4}{|c|}{$\begin{array}{c}\text { Single } \\
\mathrm{N}=20,407\end{array}$} & \multicolumn{4}{|c|}{$\begin{array}{c}\text { Married/partnered } \\
\mathrm{N}=38,240\end{array}$} \\
\hline & Mean & Std. Dev. & Min & Max & Mean & Std. Dev. & Min & Max \\
\hline Widowed & 0.622 & 0.485 & 0 & 1 & 0 & 0 & 0 & 0 \\
\hline Separated/divorced & 0.296 & 0.456 & 0 & 1 & 0 & 0 & 0 & 0 \\
\hline Never married & 0.081 & 0.273 & 0 & 1 & 0 & 0 & 0 & 0 \\
\hline Age & 72.91 & 10.38 & 55 & 109 & 67.95 & 8.33 & 55 & 102 \\
\hline Female & 0.758 & 0.428 & 0 & 1 & 0.473 & 0.499 & 0 & 1 \\
\hline \multicolumn{9}{|l|}{ Race } \\
\hline White & 0.761 & 0.426 & 0 & 1 & 0.865 & 0.342 & 0 & 1 \\
\hline Black & 0.195 & 0.397 & 0 & 1 & 0.096 & 0.295 & 0 & 1 \\
\hline Other & 0.043 & 0.203 & 0 & 1 & 0.039 & 0.193 & 0 & 1 \\
\hline Hispanic & 0.086 & 0.281 & 0 & 1 & 0.081 & 0.273 & 0 & 1 \\
\hline \multicolumn{9}{|l|}{ Education } \\
\hline Less than High School & 0.293 & 0.455 & 0 & 1 & 0.197 & 0.398 & 0 & 1 \\
\hline GED & 0.041 & 0.198 & 0 & 1 & 0.046 & 0.208 & 0 & 1 \\
\hline High School Graduate & 0.323 & 0.468 & 0 & 1 & 0.314 & 0.464 & 0 & 1 \\
\hline Some College & 0.198 & 0.399 & 0 & 1 & 0.214 & 0.410 & 0 & 1 \\
\hline College + & 0.144 & 0.351 & 0 & 1 & 0.230 & 0.421 & 0 & 1 \\
\hline \multicolumn{9}{|c|}{ Monthly Out-of-Pocket Medical Spending (in 2010 dollars) } \\
\hline Total & 162.55 & 693.80 & 0 & 32,684 & 148.03 & 730.25 & 0 & 94,215 \\
\hline Hospital & 9.01 & 107.45 & 0 & 11,933 & 12.25 & 487.48 & 0 & 93,441 \\
\hline Doctor & 11.64 & 43.47 & 0 & 1,388 & 16.13 & 64.19 & 0 & 5,671 \\
\hline Outpatient Surgery & 3.12 & 60.91 & 0 & 7,893 & 4.10 & 34.15 & 0 & 2,180 \\
\hline Prescription Drugs & 92.54 & 600.88 & 0 & 32,642 & 84.81 & 514.97 & 0 & 68,004 \\
\hline Dental & 21.15 & 64.47 & 0 & 1,735 & 26.66 & 69.17 & 0 & 2,855 \\
\hline Nursing Home & 21.99 & 273.49 & 0 & 18,309 & 2.98 & 74.58 & 0 & 4,575 \\
\hline Home Care & 2.26 & 60.16 & 0 & 4,096 & 0.55 & 22.14 & 0 & 2,205 \\
\hline Other & 0.84 & 20.10 & 0 & 1,805 & 0.55 & 11.20 & 0 & 963 \\
\hline \multicolumn{9}{|c|}{ Prob (Health Care Utilization over Previous 2 Years) } \\
\hline Hospital Stay & 0.302 & 0.459 & 0 & 1 & 0.245 & 0.430 & 0 & 1 \\
\hline Doctor Visit & 0.942 & 0.234 & 0 & 1 & 0.949 & 0.220 & 0 & 1 \\
\hline Outpatient Surgery & 0.200 & 0.400 & 0 & 1 & 0.217 & 0.412 & 0 & 1 \\
\hline Dental Visit & 0.848 & 0.359 & 0 & 1 & 0.827 & 0.379 & 0 & 1 \\
\hline Regularly Take Rx & 0.524 & 0.499 & 0 & 1 & 0.667 & 0.471 & 0 & 1 \\
\hline Nursing Home Stay & 0.061 & 0.240 & 0 & 1 & 0.018 & 0.131 & 0 & 1 \\
\hline Home Health Care & 0.109 & 0.312 & 0 & 1 & 0.055 & 0.229 & 0 & 1 \\
\hline Special Health Facility & 0.110 & 0.312 & 0 & 1 & 0.071 & 0.257 & 0 & 1 \\
\hline \multicolumn{9}{|c|}{ Degree of Health Care Utilization over Previous 2 Years } \\
\hline Number of Hospital Stays & 0.534 & 1.211 & 0 & 50 & 0.405 & 1.057 & 0 & 60 \\
\hline Number of Doctor Visits & 11.090 & 17.410 & 0 & 609 & 10.082 & 18.710 & 0 & 900 \\
\hline Nights in Hospital & 2.945 & 11.508 & 0 & 614 & 1.918 & 7.727 & 0 & 320 \\
\hline Nights in Nursing Home & 12.420 & 81.709 & 0 & 1,005 & 1.649 & 26.544 & 0 & 945 \\
\hline \multicolumn{9}{|l|}{ Insurance Coverage } \\
\hline Medicare & 0.774 & 0.418 & 0 & 1 & 0.629 & 0.483 & 0 & 1 \\
\hline Medicaid & 0.147 & 0.354 & 0 & 1 & 0.041 & 0.198 & 0 & 1 \\
\hline Champus/VA & 0.043 & 0.203 & 0 & 1 & 0.065 & 0.246 & 0 & 1 \\
\hline Private Plan & 0.536 & 0.499 & 0 & 1 & 0.697 & 0.459 & 0 & 1 \\
\hline Long-Term Care Insurance & 0.099 & 0.298 & 0 & 1 & 0.139 & 0.346 & 0 & 1 \\
\hline Fair/Poor Health Status & 0.328 & 0.469 & 0 & 1 & 0.430 & 0.495 & 0 & 1 \\
\hline Number of Health Conditions & 2.356 & 1.477 & 0 & 8 & 1.997 & 1.390 & 0 & 8 \\
\hline Number of ADLs & 0.512 & 1.123 & 0 & 5 & 0.239 & 0.769 & 0 & 5 \\
\hline Number of IADLs & 0.491 & 1.143 & 0 & 5 & 0.205 & 0.726 & 0 & 5 \\
\hline Spouse in Nursing Home & 0.000 & 0.000 & 0 & 0 & 0.009 & 0.093 & 0 & 1 \\
\hline
\end{tabular}

Notes: Observations at the person-year level. Sample excludes individuals under age 55.

Source: Health and Retirement Study (HRS), Waves 6-9, 2002-2008. 
Table 2: Effect of Marital Status on Monthly Out-of-Pocket Medical Spending

\begin{tabular}{|c|c|c|c|c|c|c|c|c|c|}
\hline & (1) & (2) & (3) & (4) & $(5)$ & (6) & (7) & (8) & (9) \\
\hline VARIABLES & Total & Hospital & Doctor & $\begin{array}{c}\text { Outpatient } \\
\text { Surgery }\end{array}$ & $\begin{array}{l}\text { Prescription } \\
\text { Drugs }\end{array}$ & Dental & $\begin{array}{l}\text { Nursing } \\
\text { Home }\end{array}$ & Home Care & $\begin{array}{c}\text { Other (Sp. } \\
\text { Health } \\
\text { Facility) }\end{array}$ \\
\hline Widowed & $\begin{array}{c}43.06 * * \\
(17.29)\end{array}$ & $\begin{array}{l}0.0717 \\
(1.868)\end{array}$ & $\begin{array}{l}-0.617 \\
(1.133)\end{array}$ & $\begin{array}{c}3.303 \\
(3.856)\end{array}$ & $\begin{array}{c}10.52 \\
(12.84)\end{array}$ & $\begin{array}{c}4.158 * * \\
(1.661)\end{array}$ & $\begin{array}{c}24.82 * * \\
(10.32)\end{array}$ & $\begin{array}{c}0.971 \\
(1.441)\end{array}$ & $\begin{array}{l}-0.164 \\
(0.430)\end{array}$ \\
\hline Separated/divorced & $\begin{array}{l}-8.916 \\
(26.95)\end{array}$ & $\begin{array}{l}-1.196 \\
(4.757)\end{array}$ & $\begin{array}{l}-1.389 \\
(1.794)\end{array}$ & $\begin{array}{c}1.900 \\
(2.176)\end{array}$ & $\begin{array}{l}-27.30 \\
(24.88)\end{array}$ & $\begin{array}{c}1.487 \\
(2.138)\end{array}$ & $\begin{array}{c}17.69 * * * \\
(6.322)\end{array}$ & $\begin{array}{l}-0.783 \\
(1.932)\end{array}$ & $\begin{array}{c}0.670 \\
(0.524)\end{array}$ \\
\hline Never married & $\begin{array}{c}26.98 \\
(17.04)\end{array}$ & $\begin{array}{l}-1.582 \\
(3.016)\end{array}$ & $\begin{array}{c}2.431 \\
(3.233)\end{array}$ & $\begin{array}{c}4.737 \\
(2.905)\end{array}$ & $\begin{array}{l}-0.646 \\
(13.66)\end{array}$ & $\begin{array}{c}1.425 \\
(2.848)\end{array}$ & $\begin{array}{c}20.39 * * * \\
(7.035)\end{array}$ & $\begin{array}{l}0.0929 \\
(1.110)\end{array}$ & $\begin{array}{c}0.136 \\
(0.275)\end{array}$ \\
\hline Observations & 58,647 & 58,647 & 58,647 & 58,647 & 58,647 & 58,647 & 58,647 & 58,647 & 58,647 \\
\hline R-squared & 0.005 & 0.001 & 0.005 & 0.001 & 0.005 & 0.004 & 0.025 & 0.017 & 0.004 \\
\hline Number of individuals & 19,944 & 19,944 & 19,944 & 19,944 & 19,944 & 19,944 & 19,944 & 19,944 & 19,944 \\
\hline \multicolumn{10}{|c|}{ Dependent Variable Mean: } \\
\hline Married & 148.03 & 12.25 & 16.13 & 4.1 & 84.81 & 26.66 & 2.98 & 0.55 & 0.55 \\
\hline Married and Nonzero & 164.03 & 136.69 & 28.51 & 47.27 & 122.71 & 46.42 & 567.76 & 79.91 & 26.17 \\
\hline
\end{tabular}

Robust standard errors in parentheses

$* * * \mathrm{p}<0.01, * * \mathrm{p}<0.05, * \mathrm{p}<0.1$

Notes: Dependent variable as indicated in 2010 dollars. All specifications include age, year, and individual fixed effects. Regressions are unweighted. Standard errors clustered by household. 
Table 3: Effect of Marital Status on Prob (Health Care Utilization) and Degree of Health Care Utilization Over Previous 2 Years

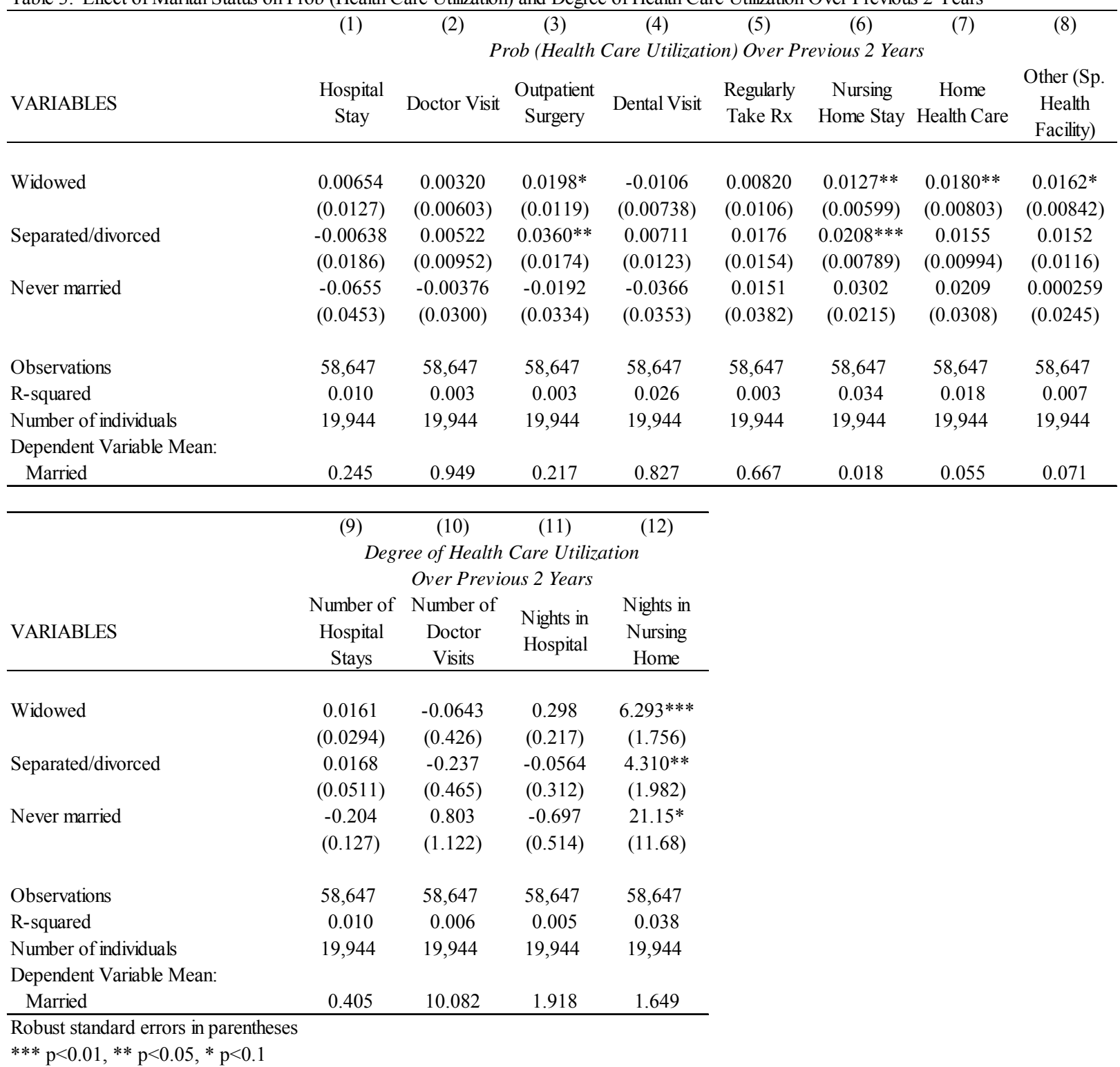

Notes: Dependent variable as indicated. All specifications include age, year, and individual fixed effects. Regressions are unweighted. Standard errors clustered by household. 
Table 4: Effect of Marital Status on Monthly Out-of-Pocket Medical Spending: Health Status and Insurance Controls

\begin{tabular}{|c|c|c|c|c|c|c|c|c|c|}
\hline & (1) & (2) & (3) & (4) & (5) & (6) & (7) & (8) & (9) \\
\hline VARIABLES & Total & Hospital & Doctor & $\begin{array}{c}\text { Outpatient } \\
\text { Surgery }\end{array}$ & $\begin{array}{l}\text { Prescription } \\
\text { Drugs }\end{array}$ & Dental & $\begin{array}{l}\text { Nursing } \\
\text { Home }\end{array}$ & Home Care & $\begin{array}{c}\text { Other (Sp. } \\
\text { Health } \\
\text { Facility) }\end{array}$ \\
\hline Widowed & $\begin{array}{c}41.56^{* *} \\
(16.82)\end{array}$ & $\begin{array}{l}-0.136 \\
(2.042)\end{array}$ & $\begin{array}{l}-0.350 \\
(1.131)\end{array}$ & $\begin{array}{c}3.421 \\
(3.882)\end{array}$ & $\begin{array}{c}11.68 \\
(12.86)\end{array}$ & $\begin{array}{c}4.172 * * \\
(1.661)\end{array}$ & $\begin{array}{c}22.14^{* *} \\
(9.561)\end{array}$ & $\begin{array}{c}0.815 \\
(1.450)\end{array}$ & $\begin{array}{l}-0.179 \\
(0.429)\end{array}$ \\
\hline Separated/divorced & $\begin{array}{l}-12.75 \\
(26.63)\end{array}$ & $\begin{array}{l}-1.460 \\
(4.772)\end{array}$ & $\begin{array}{l}-1.238 \\
(1.770)\end{array}$ & $\begin{array}{c}1.983 \\
(2.174)\end{array}$ & $\begin{array}{l}-26.72 \\
(24.74)\end{array}$ & $\begin{array}{c}1.623 \\
(2.132)\end{array}$ & $\begin{array}{c}13.47 * * \\
(5.760)\end{array}$ & $\begin{array}{l}-1.048 \\
(1.938)\end{array}$ & $\begin{array}{c}0.644 \\
(0.517)\end{array}$ \\
\hline Never married & $\begin{array}{c}22.41 \\
(18.04)\end{array}$ & $\begin{array}{c}0.101 \\
(4.088)\end{array}$ & $\begin{array}{c}3.038 \\
(3.234)\end{array}$ & $\begin{array}{l}4.985^{*} \\
(2.932)\end{array}$ & $\begin{array}{l}-1.005 \\
(13.92)\end{array}$ & $\begin{array}{c}1.241 \\
(2.866)\end{array}$ & $\begin{array}{l}14.23 * \\
(7.511)\end{array}$ & $\begin{array}{l}-0.192 \\
(1.315)\end{array}$ & $\begin{array}{l}0.0115 \\
(0.298)\end{array}$ \\
\hline Observations & 58647 & 58647 & 58647 & 58647 & 58647 & 58647 & 58647 & 58647 & 58647 \\
\hline R-squared & 0.008 & 0.003 & 0.007 & 0.002 & 0.007 & 0.004 & 0.059 & 0.021 & 0.006 \\
\hline Number of individuals & 19944 & 19944 & 19944 & 19944 & 19944 & 19944 & 19944 & 19944 & 19944 \\
\hline \multicolumn{10}{|l|}{ Dependent Variable Mean: } \\
\hline Married & 148.03 & 12.25 & 16.13 & 4.1 & 84.81 & 26.66 & 2.98 & 0.55 & 0.55 \\
\hline Married and Nonzero & 164.03 & 136.69 & 28.51 & 47.27 & 122.71 & 46.42 & 567.76 & 79.91 & 26.17 \\
\hline
\end{tabular}

Robust standard errors in parentheses

$* * * \mathrm{p}<0.01, * * \mathrm{p}<0.05, * \mathrm{p}<0.1$

Notes: Dependent variable as indicated in 2010 dollars. All specifications include age, year, and individual fixed effects. Regressions are unweighted. Health status and insurance controls include self-reported health status indicator variables, indicator variables for number of ADLs and IADLs, and indicator variables for the number of health conditions ever had. See text for more details. Standard errors clustered by household. 
Table 5: Effect of Marital Status on Monthly Out-of-Pocket Medical Spending: Interaction with Gender

\begin{tabular}{|c|c|c|c|c|c|c|c|c|c|}
\hline & (1) & (2) & (3) & (4) & (5) & (6) & (7) & (8) & (9) \\
\hline VARIABLES & Total & Hospital & Doctor & $\begin{array}{l}\text { Outpatient } \\
\text { Surgery }\end{array}$ & $\begin{array}{l}\text { Prescription } \\
\text { Drugs }\end{array}$ & Dental & $\begin{array}{l}\text { Nursing } \\
\text { Home }\end{array}$ & Home Care & $\begin{array}{c}\text { Other (Sp. } \\
\text { Health } \\
\text { Facility) }\end{array}$ \\
\hline Widowed & $\begin{array}{c}31.32 \\
(24.19)\end{array}$ & $\begin{array}{l}-0.943 \\
(3.862)\end{array}$ & $\begin{array}{l}-2.415 \\
(2.389)\end{array}$ & $\begin{array}{l}-0.929 \\
(1.092)\end{array}$ & $\begin{array}{c}10.28 \\
(18.85)\end{array}$ & $\begin{array}{c}0.494 \\
(2.674)\end{array}$ & $\begin{array}{c}19.96 \\
(12.47)\end{array}$ & $\begin{array}{c}4.652 \\
(4.886)\end{array}$ & $\begin{array}{c}0.216 \\
(0.547)\end{array}$ \\
\hline Widowed X Female & $\begin{array}{c}17.66 \\
(32.56)\end{array}$ & $\begin{array}{c}1.248 \\
(4.588)\end{array}$ & $\begin{array}{c}2.665 \\
(2.712)\end{array}$ & $\begin{array}{c}6.052 \\
(5.682)\end{array}$ & $\begin{array}{c}1.407 \\
(24.36)\end{array}$ & $\begin{array}{l}5.562 * \\
(3.371)\end{array}$ & $\begin{array}{c}6.378 \\
(18.39)\end{array}$ & $\begin{array}{l}-5.200 \\
(4.904)\end{array}$ & $\begin{array}{l}-0.452 \\
(0.777)\end{array}$ \\
\hline Divorced & $\begin{array}{l}-0.587 \\
(17.49)\end{array}$ & $\begin{array}{l}-6.920 \\
(6.765)\end{array}$ & $\begin{array}{l}-4.346 \\
(3.214)\end{array}$ & $\begin{array}{l}1.010 \\
(1.832)\end{array}$ & $\begin{array}{l}-3.242 \\
(8.355)\end{array}$ & $\begin{array}{c}0.433 \\
(2.671)\end{array}$ & $\begin{array}{c}15.86 \\
(10.16)\end{array}$ & $\begin{array}{l}-3.622 \\
(5.149)\end{array}$ & $\begin{array}{c}0.239 \\
(0.217)\end{array}$ \\
\hline Divorced X Female & $\begin{array}{l}-12.13 \\
(44.30)\end{array}$ & $\begin{array}{c}8.868 \\
(9.139)\end{array}$ & $\begin{array}{c}4.999 \\
(3.879)\end{array}$ & $\begin{array}{c}1.898 \\
(4.131)\end{array}$ & $\begin{array}{l}-37.37 \\
(39.31)\end{array}$ & $\begin{array}{c}2.305 \\
(4.105)\end{array}$ & $\begin{array}{c}2.601 \\
(13.29)\end{array}$ & $\begin{array}{c}3.900 \\
(5.244)\end{array}$ & $\begin{array}{c}0.669 \\
(0.841)\end{array}$ \\
\hline Never married & $\begin{array}{c}7.467 \\
(20.38)\end{array}$ & $\begin{array}{l}-3.481 \\
(3.590)\end{array}$ & $\begin{array}{l}-1.153 \\
(2.029)\end{array}$ & $\begin{array}{c}3.604 \\
(3.294)\end{array}$ & $\begin{array}{c}1.414 \\
(18.46)\end{array}$ & $\begin{array}{l}-3.089 \\
(4.322)\end{array}$ & $\begin{array}{l}10.99 * \\
(5.922)\end{array}$ & $\begin{array}{l}-0.882 \\
(2.196)\end{array}$ & $\begin{array}{l}0.0669 \\
(0.209)\end{array}$ \\
\hline Never married X Female & $\begin{array}{c}32.46 \\
(31.61)\end{array}$ & $\begin{array}{c}3.843 \\
(5.790)\end{array}$ & $\begin{array}{c}5.551 \\
(4.961)\end{array}$ & $\begin{array}{c}2.412 \\
(5.668)\end{array}$ & $\begin{array}{l}-0.347 \\
(26.65)\end{array}$ & $\begin{array}{c}6.784 \\
(5.700)\end{array}$ & $\begin{array}{c}13.39 \\
(12.26)\end{array}$ & $\begin{array}{c}0.810 \\
(2.397)\end{array}$ & $\begin{array}{l}0.0196 \\
(0.488)\end{array}$ \\
\hline Observations & 58,647 & 58,647 & 58,647 & 58,647 & 58,647 & 58,647 & 58,647 & 58,647 & 58,647 \\
\hline R-squared & 0.006 & 0.001 & 0.006 & 0.002 & 0.006 & 0.005 & 0.028 & 0.030 & 0.005 \\
\hline $\begin{array}{l}\text { Number of individuals } \\
\text { Dependent Variable Mean }\end{array}$ & 19,944 & 19,944 & 19,944 & 19,944 & 19,944 & 19,944 & 19,944 & 19,944 & 19,944 \\
\hline Married & 148.03 & 12.25 & 16.13 & 4.1 & 84.81 & 26.66 & 2.98 & 0.55 & 0.55 \\
\hline Married and Nonzero & 164.03 & 136.69 & 28.51 & 47.27 & 122.71 & 46.42 & 567.76 & 79.91 & 26.17 \\
\hline
\end{tabular}

Robust standard errors in parentheses

$* * * \mathrm{p}<0.01, * * \mathrm{p}<0.05, * \mathrm{p}<0.1$

Notes: Dependent variable as indicated in 2010 dollars. All specifications include age, year, and individual fixed effects. Regressions are unweighted. Standard errors clustered by household. 
Table 6: Effect of Marital Status on Monthly Out-of-Pocket Medical Spending: Sensitivity and Robustness Checks

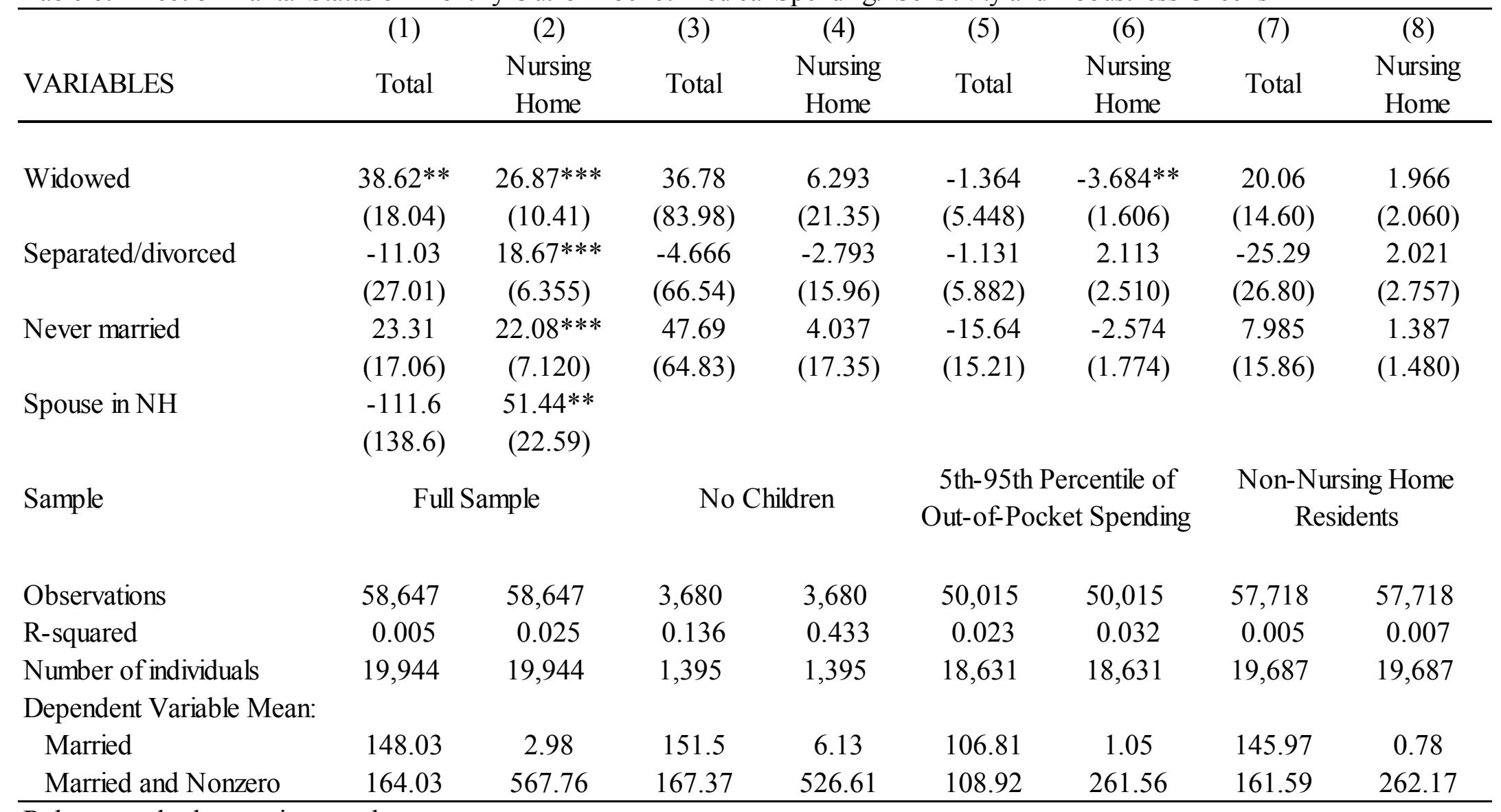

Robust standard errors in parentheses

$* * * \mathrm{p}<0.01, * * \mathrm{p}<0.05, * \mathrm{p}<0.1$

Notes: Dependent variable as indicated in 2010 dollars. All specifications include age, year, and individual fixed effects. Regressions are unweighted. Standard errors clustered by household. 
Table 7: Percent of Differences in Monthly Out-of-Pocket Medical Spending by Gender Explained by Differences in Marital Status by Gender

(a) All Out-of-Pocket Medical Spending

\begin{tabular}{cccc}
\hline & $\bar{Z}_{a, \text { women }}-\bar{Z}_{a, \text { men }}$ & $\begin{array}{c}\text { Percent of } \\
\text { Difference }\end{array}$ \\
& $\begin{array}{c}\text { Specification 1 } \\
\text { (without marital }\end{array}$ & $\begin{array}{c}\text { Specification 2 } \\
\text { (with marital }\end{array}$ & $\begin{array}{c}\text { Explained by } \\
\text { Marital Status }\end{array}$ \\
Age Group (a) & status controls) & status controls) & $\left(\theta_{a}\right)$ \\
\hline $55-59$ & $\$ 22.14$ & $\$ 19.31$ & $12.8 \%$ \\
$60-64$ & $\$ 29.67$ & $\$ 25.22$ & $15.0 \%$ \\
$65-69$ & $\$ 13.51$ & $\$ 6.32$ & $53.2 \%$ \\
$70-74$ & $\$ 12.59$ & $\$ 3.16$ & $74.9 \%$ \\
$75-79$ & $\$ 8.97$ & $-\$ 3.08$ & $134.3 \%$ \\
$80-84$ & $\$ 39.58$ & $\$ 23.37$ & $40.9 \%$ \\
$85-89$ & $\$ 8.00$ & $-\$ 9.21$ & $215.1 \%$ \\
$90+$ & $\$ 49.64$ & $\$ 31.48$ & $36.6 \%$ \\
\hline Total (all ages) & $\$ 25.19$ & $\$ 16.27$ & $35.4 \%$ \\
\hline
\end{tabular}

(b) Nursing Home Out-of-Pocket Spending

\begin{tabular}{|c|c|c|c|}
\hline \multirow[b]{2}{*}{ Age Group ( $a$ ) } & \multicolumn{2}{|c|}{$\bar{Z}_{a, \text { women }}-\bar{Z}_{a, \text { men }}$} & \multirow{2}{*}{$\begin{array}{c}\text { Percent of } \\
\text { Difference } \\
\text { Explained by } \\
\text { Marital Status } \\
\left(\theta_{a}\right)\end{array}$} \\
\hline & $\begin{array}{l}\text { Specification } 1 \\
\text { (without marital } \\
\text { status controls) }\end{array}$ & $\begin{array}{l}\text { Specification } 2 \\
\text { (with marital } \\
\text { status controls) }\end{array}$ & \\
\hline $55-59$ & $\$ 0.34$ & $-\$ 2.55$ & $841.0 \%$ \\
\hline $60-64$ & $-\$ 0.39$ & $-\$ 4.19$ & $-968.7 \%$ \\
\hline $65-69$ & $-\$ 0.89$ & $-\$ 6.22$ & $-600.9 \%$ \\
\hline $70-74$ & $\$ 4.01$ & $-\$ 2.66$ & $166.4 \%$ \\
\hline $75-79$ & $\$ 7.51$ & $-\$ 0.14$ & $101.9 \%$ \\
\hline $80-84$ & $\$ 16.84$ & $\$ 7.02$ & $58.3 \%$ \\
\hline $85-89$ & $\$ 19.52$ & $\$ 9.41$ & $51.8 \%$ \\
\hline $90+$ & $\$ 29.73$ & $\$ 19.08$ & $35.8 \%$ \\
\hline Total (all ages) & $\$ 3.15$ & $-\$ 2.96$ & $194.0 \%$ \\
\hline
\end{tabular}

Notes: Specification 1 includes age, year, and individual fixed effects. Specification 2 includes age, year, individual fixed effects AND marital status controls. See text for more details. 